\title{
ЕДИНАЯ МЕБИУСНАЯ СУЩНОСТЬ И ЦЕЛОСТНОСТЬ
}

\begin{abstract}
Аннотация. Логическим основанием для написания статьи служит свойство неделимости ленты Мебиуса, которое остется еще неизученным. Формулировка, характеризующая ленту «односторонней», с самого начала ее объявления вызвала критику сторонников бифуркационного подхода, обосновывающих теорию раздвоение природы. Автор, отвлекаясь от количественной стороны вопроса, подвергает анализу не стороны ленты, имеющие определенную размерность, а ленту в месте взаимоперхода сторон, где размерности перестают различаться, образуя уникальную сферу мебиусного пространства. Обобщение исследований реализовано в понятии «целостность», которое выводится из наглядно и чувственно наблюдаемой в реальном пространстве ленты Мёбиуса конечной неделимости. Это позволяет подойти к решению важных мировоззренческих вопросов о неделимости и взаимопревращаемости материи. Эти свойства эксперементально обнаруживаются в ленте Мёбиуса и подчиняются строгому верифицируемому закону. Его сущность выражает протяженность материи, которая отвечает за свое сохранение, устойчивое равновесие и неуничтожимость. Мир не может иметь «дырок», «границ» и «разрывов». Из этого вытекают Метафизические обобщения, важные также для научного и человеческого плана. Они позволяют целостно подойти к решению гипотезы Пуанкаре, подвергнуть анализу $V$ постулат Евклида, оценить истинные свойства единого, принадлежащие человеку, как неделимой по природе сущности, который может по своей воле конструировать мир, существующий по законам этой сущности.
\end{abstract}

Ключевъе слова: целостность, конечная неделимость, единство, протяженность, взаимопревращаемость, пространственная однородность, уникальная сфера, целостная симметрия, движение, сохранение.

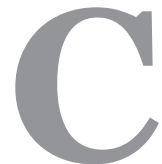

уть настоящей статьи заключается в попытке обосновать неделимую природу мебиусной ленты, которая может быть вполне наглядной и чувственно наблюдаемой в ее реальном пространстве. Философским основанием исследования будет служить концепция целостности, так как единственным приемлемым способом, позволяющим изучить целостные свойства объекта, могут быть свойства самой целостности. Соответствующие философские обобщения будут сделаны с помощью понятия «целостность», выводимого из экспериментально установленной конечной неделимости ленты Мёбиуса.

По Блаубергу, «Целостность (wholeness, die Ganzheit, la integrite) - это представление о полноте охвата явлений и вместе с тем о сущности интеграции, процессах новообразования, струк- турных уровнях, иерархической организации процессов и явлений и т.п., в каждый данный момент в философском и научном познании. Это - фон, на котором развертывается познание целостных существующих объектов, ориентир познавательной деятельности. Эту функцию понятие целостности выполняет в силу того, что оно имеет своеобразную двухслойную структуру, включая в себя не только актуальное, но и потенциальное знание ${ }^{1}$.

Зародившись в лоне поисков единства мира, целостность существовала на протяжении всей истории человечества. Античный историк греческой философии Диоген Лаэртский засвидетельствовав учение мифического Мусея писал, что «все на свете рождается из Единого

\footnotetext{
${ }^{1}$ Блауберг И.В. Проблема целостности и системный подход. М.: Эдиториал УРСС, 1997. С. 159.
} 


\section{Философия и культура 12(72) • 2013}

и разрешается в Едином»'. Эта идея более тридцати веков объединяла многих мыслителей: Парменида, Платона, Аристотеля, Плотина, Фому Аквинского, Н. Кузанского, Джордано Бруно, Гольбаха и др., создавая разнообразные преломления. Положение Парменида «мыслить - то же, что и быть», говорит о том, что логические аргументы относятся не просто к области разума, но и к области бытия, и то, что мы исследуем при помощи разума, непосредственно относится и к бытию. Бытие Парменида едино и не имеет частей. Платон, развив это положение, утверждал, что «не имея частей, единое не может иметь ни начала, ни конца, ни середины; не может иметь частей, а значит, не может быть целым, ибо целое - это то, что имеет части» ${ }^{2}$. Аристотель единое характеризовал родовым понятием по отношению к целому, на основании чего распространил признаки первого на второе 3 . У основоположника Неоплатонизма - Плотина единое выражало трансцендентное начало, которое выше всего сущего, которое предшествует всему мыслимому. Кузанец в поисках мудрости выражал единое через единицу, единственное предназначение которой состояло в возможности осуществлять бытие. Исходя из этого, реальность он связывал с многообразием, бытие которого не возможно было без соучастия единого ${ }^{4}$.

Гораздо позже единое было сведено к понятию система, а целостный опыт отошел на второй план, сделавшись элементом подсистемы, связей, отношений, структуры. В.Н. Кузнецов справедливо назвал методологию этого времени «корпускулярно-аналитической»5.

Попытка вновь заглянуть в потусторонний мир явлений И. Кантом в книге «Критика чистого разума», сменила вектор мышления многих европейских философов на конструктивистский. Сравнивая систему и целостность,

\footnotetext{
${ }^{1}$ Диаген Лаэртский. О жизни, учениях и изречениях знаменитых философов. М., 1963. С. 63-64.

${ }^{2}$ Платон. Избранные диалоги / сост. и коммент. В.В. Шкоды. М.: АСТ, 2006. С. 344.

${ }^{3}$ Аристотель. Сочинения. В 4-х т. Т. І. М., 1975-1983. С. 153, 175.

${ }^{4}$ Nikolaus von Kues. Die Jagd nach Weisheit. Philosophischtheologische Werke. Band 4. Felix Meiner Verlag, Hamburg 2002. S. 89.

${ }^{5}$ Кузнецов В.Н. Французский материализм XVIII века / В.Н. Кузнецов. М.: Мысль, 1981. С. 303.
}

К. Маркс гениально заметил, что система не может быть тождественна целостности. В одном из своих трудов он написал: - «Система становится целостностью, целостной системой, когда она начинает производить свои предпосылки, то есть, воспроизводить себя на своей собственной основе» ${ }^{6}$ Несмотря на многие старания ученых придать понятию «целостность» важное значение, оно не стало определяющим ни в науке, ни в философии. Обобщить итоги длительного периода исследования целостности можно высказыванием Г. А. Смирнова, который назвал многочисленные попытки, «дать логически корректное определение понятия целостности, неудачными».

Следовательно, в настоящее время нет общепринятой системы основных понятий о целостности ни у нас в стране, ни за ее пределами, поэтому ее продолжают сводить к понятию «целое». Так, авторы монографии «Концепция целостности» И. З. Цехмистро и В. И. Штанько, характеризуя целостность, как «уникальное свойство неделимости и неразложимости на множества каких-либо элементов», продолжают ее оценивать «как подлинно целое» 8 . Очевидно, что, стремясь к единому, как попытке обосновать сущность интеграции, ученые привычно уделяют большее значение системе, основанной на теории множеств. Доверяя эмпирическому методу исследования, многие называют «сложное новым научным словарем»9, отвергая при этом значение философской сути вопроса о едином, которое имеет особую значимость для мировоззренческого, научного и человеческого плана. Возможно, что такой подход является одной из причин, который позволяет «односторонне» идентифицировать ленту Мёбиуса, называя это частным случаем, как бы абсурдно это не звучало.

Поэтому в статье мы будем следовать мыслителям, которые выкристаллизовали поня-

\footnotetext{
${ }_{6}^{6}$ Маркс К., Энгельс Ф. Сочинения. Т. 46. Ч. 1. С. 229.

${ }^{7}$ Смирнов Г.А. Целостность и конструктивность: постановка проблемы // Логика и системные методы анализа научного знания: Тез. докл. к IX Всесоюзн. совещ. по логике, методологии и философии науки. М., 1986. С. 112-116.

${ }^{8}$ Цехмистро И.З., Штанько В.И. Концепция целостности. Харьков: Изд-во гос. ун-та, 1987. С. 4.

${ }^{9}$ Николис Г., Пригожин И. Познание сложного. Введение / Пер. с англ. Предисл. Г.Г. Малинецкого. Изд. 3-е, доп. М.: Изд-во ЛКИ. 2008. С. 8.
} 


\section{Проблемы целостного мира}

тие «единое», ставшее фундаментальным для классической греческой философии и сформировавшее в последующем целое философское направление - неоплатонизм. Эта школа определила ключевые пункты философствования огромной исторической эпохи, а вместе с тем и характер господствующего на всем ее протяжении целостного метода мышления. Как писал Н. Кузанский: «Нераздельность, в сущности, исходит от единства, равно как и различие, а также и соединение, или связь, и, так как оно является нераздельностью, оно вечно без начала, как вечное неотделимо ни от чего»'. В этой связи особую ценность для нас представляют неделимые свойства ленты Мёбиуса, указывающие на признаки единства.

Известно, что лента Мёбиуса была открыта 1858 году одновременно двумя немецкими математиками Августом Фердинандом Мёбиусом и Иоганном Бенедиктом Листингом. А. Ф. Мёбиус назвал свое открытие «первым примером» «односторонней поверхности с краем», которая не имеет ни «левой» ни правой «стороны». Доказательство теории выглядит достаточно просто. Двигаясь вдоль середины ленты, можно попасть в исходную точку, то есть в место, откуда начиналось движение. При этом направление движения по окружности всегда меняется без пересечения края на противоположное. Е.Л. Старостин из Хейджена в своей работе «The shape of a Möbius strip» назвал ленту Мёбиуса «каноническим примером односторонней поверхности»².

Тем не менее, наряду с «односторонним» подходом были выдвинуты и другие взгляды, основанные на бифуркации (раздвоении) природы. Антибифуркационистская теория природы хотя и отрицала ее раздвоение, но имела другие (данные чувственных знаний) основания утверждать, что Мир,- это «уникальное множество физически реализуемых отношений конгруэнтности, как для пространства, так и для времени» 3 , что само собой ставило вопрос

\footnotetext{
${ }^{1}$ Кузанский Н. Избранные философские сочинения. Об ученом незнании. М., 1937. С. 21.

${ }^{2}$ Starostin E.L. \& Hejden G.H.M. van der. The shape of a Möbius strip. Nature Materials 6, 563-567. (2007) Published online: 15 July 2007 (doi: 10.1038/nmat1929).

${ }^{3}$ Грюнбаум Адольф. Философские проблемы пространства и времени / Пер. с англ. Изд. 2-е, соотнесённое. М.: Едиториал УРCC, 2003. С. 55.
}

о «поверхностной односторонности» взгляда на ленту Мёбиуса и ее свойств.

Таким образом, поиски второй стороны ленты Мёбиуса не прекращались никогда. В свое время в Германии по этому поводу была учреждена специальная премия для ученых, которые смогут предоставить двухсторонний взгляд на ленту Мёбиуса. Поощрялась даже попытки обосновать наличие у неё второй стороны. Е.Л. Старостин в связи с этим также отметил, что нахождение характерной выводимой формы «односторонней поверхности» ленты «было открытой проблемой, начиная со своей первой формулировки»4.

Вопреки приверженцам «односторонней» теории, проведем два несложных опыта. Перед тем как склеить два противоположных конца прямоугольного листа, выкрасим одну его сторону, например, синей краской, вторую - белой, и, передвигая затем пальцами рук ленту Мёбиуса вдоль ее оси, легко установим: белая полоска меняется на синюю с той периодичностью, с которой мы двигаем ее в своих руках. Это доказывает, что наши указательные пальцы лежат на одной стороне ленты, двигая циклично то одну ее сторону, то другую, в то время как большие пыльцы рук фиксируют лишь движение сторон. При этом края ленты двигаются соответственно параллельно друг другу. Таким образом, можно установить равную длину сторон ленты Мёбиуса, выкрашенных в разные цвета и замкнутых друг на друга по определенной границе, что, в свою очередь, характеризует их пространственную конгруэнтность. Что касается времени, то погрешность его промежутков по длительности прохождения отрезков зависит только от скорости движения пальцев наших рук.

Попробуем стянуть ленту Мёбиуса в одну точку для того, чтобы взглянуть на нее в миниатюре. После завершения этой попытки в руках у нас появится круглый конус (рис. № 1), обладающий всеми признаками трехмерного объекта, так как наглядно мы можем наблюдать долготу, широту и высоту. Исследуя круглый конус, мы начинаем понимать, что он заключает в себе простейшие свойства. Получается так, что, закручиваясь в конус, лента Мёбиуса образует два

\footnotetext{
${ }^{4}$ Starostin E.L. \& Hejden G.H.M. van der. The shape of a Möbius strip. Nature Materials 6, 563-567 (2007) Published online: 15 July 2007 (doi: 10.1038/nmat1929).
} 


\section{Философия и культура 12(72) • 2013}

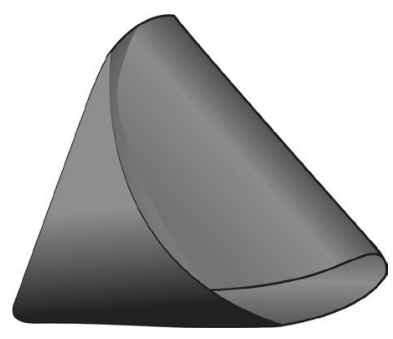

Рис. № 1. Лента Мёбиуса, стянутая в конус.

отверстия, соединяющие ее, так называемое, «внутреннее пространство» с внешним миром. Пройти путь изнутри наружу можно, не переходя пределы границ. Отверстия хотя и рассекают тело конуса от, так называемой, «вершины» до, так называемого, «основания», но при этом нет возможности определить пределы границ между вершиной и основанием, так как вершина является одновременно основанием и наоборот. По этим же причинам нет возможности определить пределы границ внутреннего и внешнего. Следовательно, образованный стягиванием ленты Мёбиуса конус соответствует описанию бутылки Клейна, у которой по определению отсутствует край ${ }^{1}$, что уже само собой противоречит первой теории, которая доказывает наличие у ленты Мёбиуса одной стороны и края.

Складывается ситуация, когда представленные выше выводы, затрагивающие один и тот же объект, имеют равноправное значение, что ставит под сомнение один из важнейших законов логики. «Объективный мир устроен таким образом, что в одном и том же предмете несовместимы (невозможны) наличие (принадлежность, обладание) и отсутствие одних и тех же признаков в одно и тоже время². Поэтому спорным представляется предложенный Поппером «критерий демаркации», который призван признавать «некоторую систему эмпирической, или научной только в том случае, если имеется возможность ее опытной проверки» ${ }^{3}$.

Если приведенные выше взгляды отражают определенную конечность ленты Мёбиуса, сводя ее либо к минимуму, либо к максимуму, рождая парадоксы, то утверждение, идентифицирующее

\footnotetext{
${ }^{1}$ Гарднер М. Профессор, у которого не было ни одной стороны // Наука и жизнь. 1977. № 5. С. 125-129.

${ }^{2}$ Гетманов А.Д. Логика: Учебник для студ. пед. вузов. М.: Высш. школа, 1986. С. 104.

${ }^{3}$ Поппер К. Логика и рост научного знания. М.: Прогресс. 1983. C. 68.
}

ленту как бесконечность, является маркером, отражающим понятие трансцендентальной значимости, в котором лента Мёбиуса представляется вне зависимости от количества ее сторон. В ней невозможно указать пределы границ, а также определить количество сторон, так как бесконечность не допускает противопоставлений. Сам Август Мёбиус не возражал против того, что теоретически поверхность может утратить «не только одну, но и обе свои стороны». Другими словами это можно выразить так, что существование «нулевых» поверхностей теоретически возможно 4 .

Независимо от того, какая теория сегодня доминирует в междисциплинарном пространстве, очевидно одно - современная наука не дает исчерпывающего ответа на давно поставленный вопрос: почему лента Мёбиуса не делится на части, имея по утверждению ученых одну часть «сторону с краем»; почему имеют место те или иные характерные свойства только для ленты Мёбиуса (формирование при делении Афганской ленты, Тысячелистника, других Парадромных фигур и пр.) 5 . По-видимому, в рамках современной научной парадигмы, базирующейся на количественном подходе, поставленные вопросы решить сложно.

Возможно, что ответ на этот вопрос лежит за пределами онтологического базиса системного подхода и кроется, как мы и упоминали, в особенностях единого. Дело в том, что все известные науке свойства Мира универсальны своей структурностью, которые поддаются подсчету. Не поэтому ли ученым сложно согласится с чем-то, что себя не проявляет? Современная математика и геометрия, отвлекаясь от всего неопределенного и подвижного в предмете исследования, описывает только статичное и определенное целое, характеризуя его части. Это подтверждает и Е. Б. Брюков, отмечая, что формальная математика по возможности пытается избегать противоречий, как «исходного пункта всего живого, в том числе «живой» мысли. На этом основании ленту Мёбиуса математики характеризуют как «одностороннюю поверхность». Данное определение «освещает только ста-

\footnotetext{
${ }^{4}$ Гарднер М. Профессор, у которого не было ни одной стороны // Наука и жизнь. 1977. № 5. С. 125-129.

5 Электронный ресурс http://de.wikipedia.org/wiki/ Möbiusband.
} 


\section{Проблемы целостного мира}

тический, лишённый движения, характер ленты Мёбиуса, в соответствие с которым она представляет собой лишь геометрическую, а не логическую фигуру»¹. А. Пуанкаре считал, что в основе работы математиков должна лежать интуиция, тогда как сама математика не допускает аналитику, что, собственно, создаёт определённые философские трудности. Рассматривая эмпирическое обоснования аксиоматического метода, он также заметил, что геометрия заимствовала у опыта только свойство твёрдых тел. «Следовательно,- говорил ученый,- если бы не было твёрдых тел в природе, не было бы и геометрии»².

В то время как наука предпочитает иметь дело с определенными «телесно-материальным» предметами, поддающимися разложению на части, философия охватывает «мыслительно-идеальную» сферу человека, характеризующую качественное своеобразие логического мышления как пути достижения истины. Самостоятельная сфера логического мышления, выделенная еще Парменидом, онтологизирована философской мыслью, как особый умопостигаемый мир, противостоящий чувственному. Философия существенно расширяет горизонт поиска. Она интуитивно ищет первооснову, как причину онтологического бытия реальности, пытается объяснить неделимость (неразложимость на части) Мира и обосновать его неуничтожимость. Поэтому неделимость ленты Мёбиуса должна вызвать у философов особый интерес к этому объекту. Не случайно Е. Брюков представляет ленту Мёбиуса в качестве «модели понятия целостности» ${ }^{3}$, называя ее «философским камнем». При этом целостность не только понятие, но и модель или образец, воплощенная в ленте Мёбиуса.

Неопределенность в себе, так чуждая точным наукам, приобретает в философии определенность для себя, что уже само по себе является движением от абстрактного к конкретному. В движении чистой мысли, по Гегелю, как поступательном движении производящего самого себя понятия, «действует» внутренняя побудительная сила, способная решить любые задачи.

\footnotetext{
${ }^{1}$ Brükov Eugen: Philosophie der Zahlen / Eugen Brückov. Treuchlingen; Berlin: Keller, 2001. S. 28.

${ }^{2}$ Пуанкаре Анри. О науке. М., 1983. С. 48.

${ }^{3}$ Brükov Eugen. Philosophe der Zhlen / Eugen Brückov. Treuchtlingen; Berlin: Keller. 2001. S. 30.
}

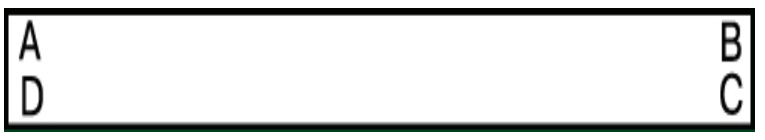

Рис. № 2. Обычный прямоугольный лист в пределах грании, $A B, B C, C D, D A$.

При достижении поставленной нами цели имеется возможность придерживаться определенных аспектов целостности:

- «инструментарного свойства» для определения взаимоперехода противоположных сторон, где единственным ограничительным инструментом будет являться движение;

- субстратного и динамического свойства;

- способа объяснения целостных свойств Мира, как единого и неделимого на составные части.

В работе будут затронуты четыре важные задачи:

- технические - рассматривающие структурные особенности становления ленты Мёбиуса;

- гносеологические - указывающие на качественный путь к разрешению количественного парадокса;

- семантические - обозначающие объект и его содержание;

- философские - обобщающие и реализующиеся в принципе целостности, выводимые из представления о взаимопереходе противоположностей как сущности интеграции в процессе бесконечного движения.

Различие между «природой неделимости», проявляющейся в мебиусной ленте и «неделимостью природы», отражающей единство в сознании, упростит, по нашему мнению, корреляцию текущих состояний мысли в процессе написания статьи и даст возможность обобщить перечисленные выше взгляды, указывая при этом, на основную методологическую предпосылку, положенную в основание исследования.

Чтобы было понятно, о чем идет речь следует рассмотреть мебиусную ленту в процессе ее конструирования. Уже с первого взгляда можно определить, что лента Мёбиуса имеет особые свойства, отличающие ее от обычного листа. Под обычным листом мы понимаем прямоугольный лист, имеющий две стороны и края в границах AB, BC, CD, DA, пределы которых образуют части листа, соответствующие его форме. Согласно Гегелю, мы вводим для ясности 


\section{Философия и культура 12(72) • 2013}

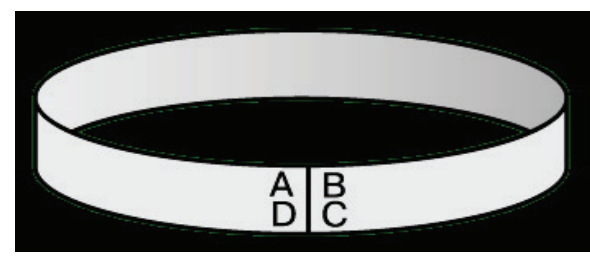

Рис. № 3. Прямоугольное кольи,о, полученное при склеивании двух противоположных краев в пределах грании, $A D$ и BC.

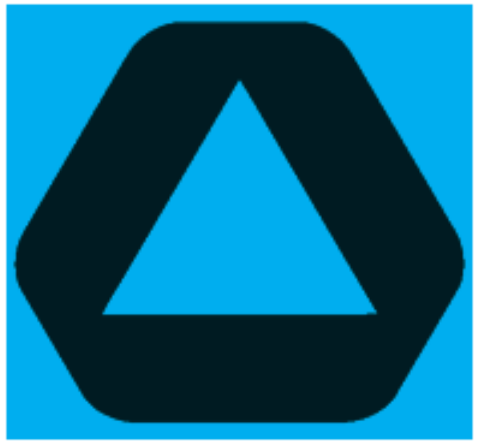

Рис. № 5. Внутренняя структура ленты Мёбиуса.

в «гнездо понятий» об объекте пару «часть - целое» с тем, чтобы определить непосредственное отношение целого и частей рассматриваемого объекта. "Содержание,- писал Гегель,- есть целое, и состоит из частей (формы) из своей противоположности. Части отличны друг от друга и самостоятельны» ${ }^{1}$. Поэтому обычный лист здесь выступает как целое, а стороны и края частями (рис. № 2).

Для того чтобы создать из прямоугольного листа кольцо, нам достаточно будет сомкнуть его противоположные прерывистые края по границам в пределах $\mathrm{AD}$ и $\mathrm{BC}$ (рис. № 3). При формировании новой фигуры происходит деформация краев обычного листа в пределах указанных границ, ведущая к их связанности, как в продольном, так и поперечном сечении, и создающая строгую ориентированность.

Кольцо получает как внутреннюю, так и внешнюю стороны, его верхний и нижний края. Указанные части сохраняют пределы прерывности. Они отличны друг от друга, самостоятельны и характеризуют пустотелый цилиндр, внутренняя сторона которого при деформации может меняться на внешнюю,

${ }^{1}$ Гегель Г.В.Ф. Энциклопедия философских наук. М., 19741977. T. 1. C. 301.

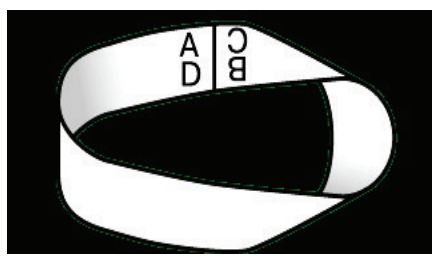

Рuc. № 4. Лист Мёбиуса.

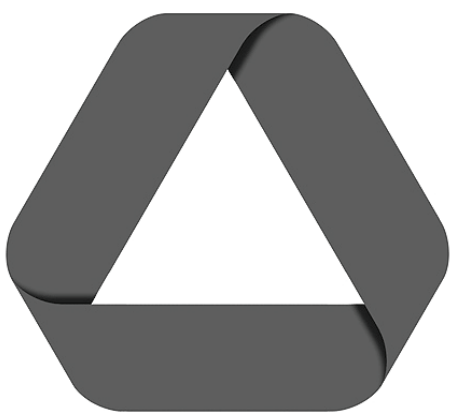

Рис. № 6. Лента Мёбиуса с внутренними и внешними уровневыми признаками и их взаимоисключение.

верхний край при этом становится нижним и наоборот.

Лист Мёбиуса приобретает свою форму, в отличие от предыдущей фигуры, не естественным с точки зрения евклидовой геометрии способом. Две противоположные параллельные линии $\mathrm{AB}$ и $\mathrm{CD}$ прямоугольного листа, поворачиваются на пол оборота по отношению друг другу примерно на $180^{\circ}$ (рис. № 4) и замыкаясь друг на друга, образуют единую и неделимую линию. Однако не все так просто, как это можно себе представить.

Для того чтобы сконструировать ленту Мёбиуса, нам понадобится сложить из прямоугольного листа (рис. № 2) последовательно три сферических угла, сумма которых и будет составлять пр. $180^{\circ}$. Становится вполне очевидным, что, деформируя прямоугольный лист в ленту Мёбиуса на поверхности стола, получить в этой плоскости хотя бы один угол - задача невыполнимая. Следовательно, при конструировании углов необходимо последовательно поднимать конец листа на определенную высоту. Становящаяся лента Мёбиуса, таким образом, как бы говорит нам, что она фигура не геометрическая, имеющая определенные строгие формы, а пространственная, приобретающая мягкие, округлые 


\section{Проблемы целостного мира}

формы. Завершающая ступень создания ленты Мёбиуса, таким образом, связана с возникновением уникального для нее пространства, в котором она приобретает свою законченную и неделимую форму (рис. № 5). Под словом неделимость мы подразумеваем конечную неделимость, исследуемого объекта.

Рассматривая техническую сторону вопроса при создании ленты Мёбиуса важно остановиться на ее, так называемых, структурных свойствах. Это можно увидеть на рисунке № 5 первоначально, как составленное из прямоугольного листа ограниченное внутреннее число углов, где каждый предыдущий для последующего выступает как необходимость, дополняющий его до единства, целостности - быть вместе. В тоже время, структура треугольника создает не только необходимую для своего существования внутреннюю пространственную среду, но формирует пространство следующего, внешнего уровня, которое также не может существовать вне своей внутренней среды (рис. № 6). Таким образом, возникает не только внутреннее или внешнее единство, но единство внутреннего и внешнего пространства, характеризующее наличие между ними взаимно-однозначного соответствия, которое и создает уникальное пространство, обуславливающее взаимодействие сторон, их взаимный переход друг в друга. Это указывает на то, что лента Мёбиуса выходит за пределы двухмерного пространства.

В связи с этим, важно подчеркнуть, что двухмерное пространство не является той средой, в которой может происходить взаимодействие. Ученые считают, что все в мире происходит в трехмерном пространстве, то есть три измерения являются тем необходимым и достаточным минимумом, в рамках которого осуществляются все типы взаимодействий материальных объектов ${ }^{1}$. Исследователи, изучающие ленту Мёбиуса, разделяли ее на две составляющие части: собственно проективную плоскость и, так называемую, «приполярную» область сферы - т.е. обычный круг, который приклеивался к ленте Мёбиуса по ее общему краю - окружности»². Предметом нашего внимания является место

\footnotetext{
${ }^{1}$ Хорошавина С.Г. Концепция современного естествознания: курс лекций. Изд. 4-е. Ростов н/Д: Феникс, 2005. 480 с.

${ }^{2}$ Смирнов С.Г. Прогулка по замкнутым поверхностям. Библиотека «Математического просвещения». Вып. 27. М.: МЦНМО, 2003. С. 28.
}

протяженности сторон ленты друг в друга, обеспечивающее им взаимодействие.

Так, в процессе конструирования ленты Мёбиуса становится ясным, что ее законченная фигура, обязанная своей целостностью предыдущему уровню (треугольнику), делает наличие ее сторон актуальными, конкретными и объективными, что и позволяет говорить о сторонах листа. Из этого следует, что все, что мы привыкли в большинстве случаев идентифицировать в геометрической (неподвижной) фигуре Мёбиуса,- это ее стороны и края, обладающие определенной широтой и долготой.

Совершенно другое дело представляет собой лист сторон ленты Мёбиуса в месте образования углов, где разные по высоте уровни образуют искривленное пространство или сферу, осуществляющую взаимный переход сторон. Поэтому лист сторон в месте их взаимного перехода не менее актуален, конкретен или объективен, однако, он трудноуловим для восприятия в силу своей сферичности. В работе «Игра в шар» Н. Кузанский, описывая сферу, говорил, что «у нее нельзя видеть ни верха, ни низа..., и все, что есть в сфере, или в округлом, есть и верх и низ, так что нельзя видеть ни его округлости, ни какой бы то ни было части»3. Это позволяет нам утверждать, что сфера, снимая уровневые пределы, создает целостную - неделимою основу ленте Мёбиуса. Становясь фигурой совершенной, лента Мёбиуса охватывает все предыдущие уровни, выступая, таким образом, пространством пространств.

Вопрос о наглядном представлении ленты Мёбиуса как пространственной модели, нами обозначен для того, чтобы показать, что «форма округлости» в месте взаимного перехода сторон снимает не только пределы различия между длинным, широким, глубоким, но и создает, как выражался Н. Кузанский, те самые удобные «для не пристрастности движения» условия. И если ей сообщить движение «по своей природе она никогда не остановится» ${ }^{4}$. Развивая идею движения, Кузанец пишет: «движется легче более округлое, так что если округлость будет максимальной, больше которой уже не может быть, она будет двигать саму же себя, то есть будет вместе и движущим и движимым»5.

\footnotetext{
${ }^{3}$ Кузанский Николай. Игра в Шар. Научн. изд. М., 2012. С. 33.

${ }^{4}$ Там же. С. 39.

${ }^{5}$ Там же. С. 41.
} 


\section{Философия и культура 12(72) • 2013}

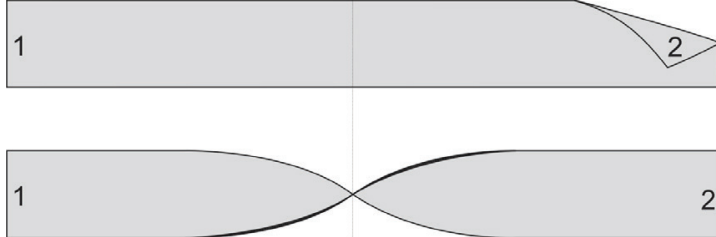

Рис. № 7а. Сверху. Двухсторонняя лента.

Рис. № 7б. Снизу. Мебиусная тента с единым пространством.

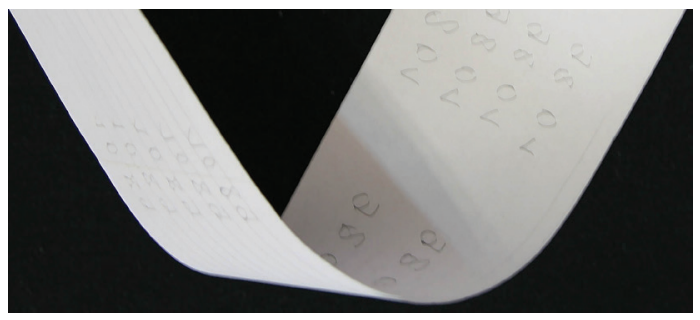

Рис. № 8. Сфера мебиусной ленты.

Е. Б. Брюков, рассматривая ленту Мёбиуса как логическую фигуру, сравнивает ее с вечным движением мысли, как целостным способом ее самоосуществления. Следовательно, логическая фигура ленты Мёбиуса всегда являет собой «постоянное движение в виде взаимоперехода сторон» ${ }^{1}$.

Рассмотрим теперь свойства мебиусной ленты с токи зрения симметрии, как инвариантности или неизменности, проявляемой при определенных преобразованиях. Так, при деформации прямоугольного листа, в котором благодаря «двухсторонней симметрии» сбалансированы, согласованны и пропорциональны все его части, он теряет свои свойства как целое. Это можно видеть наглядно на рисунках № 7а и № 7б. Две противоположные стороны листа (рис. № 7а) в результате их закручивания в разные стороны начинают утрачивать свои атрибутивные признаки (рис. № 7б) и приобретают в мебиусной ленте тождественность друг другу. Это происходит благодаря уникальным свойствам сферы, появившейся в результате скручивания (рис. № 8), где крайности листа становятся единым пространством. Поэтому мы вправе сказать, что двухсторонняя симметрия

${ }^{1}$ Brükov Eugen. Philosophie der Zahlen // Eugen Brückov. Treuchtlingen; Berlin: Keller, 2001. S. 28.

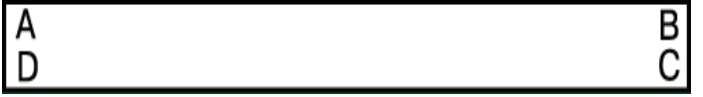

Рuc. № 9a. Лист в пределах грании $A B, B C, C D, D A$

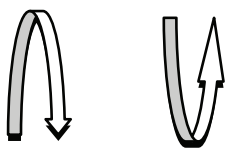

Рис. № 96. Мебиусная лента, с иентрально-симметричной осью

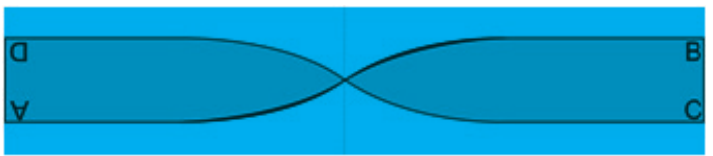

прямоугольного листа в результате деформации становится целостной симметрией в ленте Мёбиуса, обеспечивающей ей фундаментальные свойства неделимости. Понятие «целостная симметрия» здесь вводится для обозначения единства двух противоположных сторон предмета рассмотрения, которая обуславливает интеграцию, устойчивую к деформации.

Иными словами, при асимметрии каждой стороны прямоугольного листа относительно центрально-симметричной оси (рис. № 7б), нарушается прежний порядок, равновесие, согласованность, а также устойчивость их составных частей, что ведет к потере свойств целого листа. При асимметрии (деформации подвергаются две стороны одного листа), каждая из сторон, деформируясь сама, изменяет взаимно и свое положение относительно пределов другой стороны таким образом, что стороны в месте их замыкания теряют свою определенность и становятся друг для друга беспредельным, т.е. единым и неделимым пространством. Это же происходит и с краями прямоугольного листа.

Мы уже упоминали, что становление обычного прямоугольного листа в ленту Мёбиуса происходит через соединение параллельных краев или прямых в пределах границ АВ и DC определенным образом (рис.№ 4) так, что эти параллельные прямые, совпадая в обозначен- 


\section{Проблемы целостного мира}

ных точках $\mathrm{AC}$ и $\mathrm{DB}$, продолжают самих себя в обе стороны в бесконечность, сливаясь таким образом, в единую сферу. Поэтому наши выводы, относительно совпадения двух параллельных прямых в сферу, высвечивают противоречие определения Евклида относительно параллельных одной плоскости, которые «будучи продолжены в обе стороны неограниченно... между собой не встречаются» ${ }^{1}$, а если "встречаются», то только в одной точке ${ }^{2}$. И это понятно. Лента Мёбиуса - модель целостная, которая охватывает все предыдущие пространства. Претендуя на уникальность, она отражает реальную сущность действительности представленной сферы, в которой все противоположности становятся едиными. Мы можем наблюдать, как параллельные края прямоугольного листа в границах $\mathrm{AB}$, $\mathrm{CD}$ и $\mathrm{BC}, \mathrm{DA}$ (рис. № 9а), благодаря закручиванию концов $\mathrm{AD}$ и $\mathrm{BC}$ в противоположные стороны (рис. № 9б), становятся асимметричными относительно своей центрально-симметричной оси и образуют, таким образом, ту упругую энергию изгиба, которая необходима для взаимного перехода противоположностей друг в друга, обеспечивая себе, стойкое сопротивление к деформации.

В то время как глубина создает ленте Мёбиуса объемность, устойчивость ей придает упругая энергия изгиба, отвечающая за неразрывность и устойчивость. В результате асимметрии сторон и краев каждая из них, как часть некогда целого листа, теряя свою идентичность и определенность, становится взаимно-однозначной другой противоположности. Если в прямоугольном листе и созданного из него цилиндра стороны и края самостоятельны, прерывны и различаются, то в ленте Мёбиуса они совпадают, теряя свои различительные свойства. Асимметрия асимметрии рождает целостную симметрию, формируя, таким образом, в теле ленты Мёбиуса сферу пространственной однородности.

Мы можем назвать ленту Мёбиуса целостной фигурой, в которой уникальная сфера с упругой энергией изгиба создает условия для ее самоосуществления и делает ее неделимой. Так как

\footnotetext{
${ }^{1}$ Начала Евклида. Книги I-IV / Перевод с греческого и комментарии Д.Д. Мордухай-Болтовского при редакционном участии И.Н. Веселовского. М.: Ленинград: Госиздат. 1950. C. 14.

${ }^{2}$ Там же. C. 15.
}

стороны и края при совпадении в мебиусной ленте теряют свою идентичность, то термины, выражающие их различительную роль, выбывают из употребления. То, что не различимо, не может быть идентифицировано и, следовательно, формализовано. Создается опыт, который еще Гегель назвал «тотальностью». Если при описании обычного прямоугольного листа и сделанного из него кольца мы использовали простую пару: «часть-целое», то для описания ленты Мёбиуса такая необходимость отпадает в силу отсутствия у нее частей. На передний план, таким образом, выступает целостность, идентифицирующая в мебиусной ленте единство противоположных сторон.

Понятие «единство» закономерно отражает в философии атрибут материи, присущей всем объектам, то есть, то общее, что имманентно всем неорганическим, органическим и социальным системам. Это понятие для античных философов было самоочевидным и не требовало каких-либо доказательств. Единое обозначало субстрат, первоматерию, первовещество, единое начало или «основу единства однородности» ${ }^{3}$ Семантика этого слова, как мы видим, живет с тех пор своей самостоятельной жизнью, пронизывая все сферы человеческой жизни от религии до науки, включая все многообразие общественного и государственного устройства различных стран. Однако, понимается это слово по-разному. Говоря о религиозной вере, Г.Д. Левин тонко заметил, что ее «тайна в том, что она неопровержима, потому живет тысячелетия» ${ }^{4}$. И если для религии связь с Единым проявляется в виде веры, то для науки необходимы неопровержимые факты существования Единого. Для науки «существует только то, что проявляется» ${ }^{5}$ И. З. Цехмистро в своей работе точно выразил, что «целостность реализовывалась на некоторой множественной основе за счет того или иного физически-причинного связывания элементов множества в целостную совокупность» ${ }^{6}$. Однако, он тут же

\footnotetext{
${ }^{3}$ Философский словарь / Под ред. И.Т. Фролова. 5-е изд. М.: Политиздат, 1987. С. 465.

4 Левин Г.Д. Методологические принципы диалога материалистов с верующими // Вопросы философии. 2008. № 10. C. 85 .

${ }^{5}$ Там же. С. 85.

${ }^{6}$ Цехмистро И.З., Штанько В.И. и др. Концепция целостности. Харьков: Изд-во Харьковского гос. ун-та, 1987. С. 4.
} 


\section{Философия и культура 12(72) • 2013}

обоснованно сделал догадку о том, что «понятие целостности может иметь и совсем другой, еще совершенно не изученный смысл, когда целостности присущ изначальный характер (она первична)» ни частей, ни элементов, что, собственно, отличает ленту Мёбиуса от всех других объектов.

Здесь встает закономерный вопрос: как постичь единое, если его нельзя выразить через многое, которое имеет части? Ведь еще древние были убеждены в том, что единое не может быть сведено к многому. Евклид с достаточной простотой выразил это в Началах: «Единица есть (то), через что каждое из существующих считается единым. Число же - множество, составленное из единиц ${ }^{2}$. В этом случае можно сделать предположение. Чтобы точнее выразить единое в философии появилась тенденция идти от обратного, а именно: сводить противоположности в единое. Платона, как целостно мыслящего философа, нисколько не страшило единство противоположностей, наоборот - оно было для него весьма желательным, так как в едином он усматривал совпадение противоположностей, в котором снимаются все различия вещей.

Идея совпадения бесконечно минимальной кривизны с бесконечно максимальной прямизной, покоя и движения, минимума и максимума проходят красной линией во многих трудах Н. Кузанского. Совпадение противоположностей Кузанец выражает одним словом «zugleich» ${ }^{3}$ (одновременно), подчеркивая, таким образом, что не только пространство, но и время покоятся в одной точке.

Если Кузанец идентифицирует совпадение противоположностей словом «одновременно», то Гегель характеризует его словом «вместе». Он пишет: «Вместе есть противоположность, и отрицание части» 4 . В понятие «вместе» философ вкладывает тождество частей, но не абстрактное, а конкретное тождество явлений, которое осуществляется путем взаимного перехода одного в другое, совершающееся постоянно.

\footnotetext{
${ }^{1}$ Там же. С. 4.

${ }^{2}$ Начала Евклида. Книги VII-X / Перевод с греч. и комм. Д.Д. Мордухай-Болтовского при редакционном участии И.Н. Веселовского. М.-Ленинград: Госиздат, 1949. 514 с.

${ }^{3}$ Nikolaus von Kues. «Philosophisch-theologische Werke. Band 2. Mutmaßungen. Felix Meiner Verlag. Hamburg, 2002. S. 155.

${ }^{4}$ Гегель Г.В.Ф. Энциклопедия философских наук. М., 19741977. T. 1. С. 301.
}

Поэтому источником движения, по Гегелю, выступает взаимодействие противоположных сторон. Это в четкой форме он высказал на идеалистическом уровне в определении самого понятия. «Понятие,- говорит Гегель,- для своего развития не нуждается ни в каком внешнем стимуле; его собственная, включающая в себя противоречие между простотой и различием и именно потому беспокойная природа побуждает его к самоосуществлению, она заставляет его развертывать и делать в нем самом только идеально, т.е. в противоречивой форме неразличимости» 5 . Из этого высказывания следовал вывод: все, что обладает противоречием - самодвижется.

К. Маркс с позиции неразделенности взаимодействия и диалектического противоречия выразил самодвижение общественного производства. Говоря о крайних его противоположностях (производства и потребления), он указывал: «каждое из них есть не только непосредственно другое и не только опосредствует другое, но каждое из них, совершаясь, создает другое, создает себя как другое» ${ }^{6}$.

Е.Б. Брюков в своей книге «Philosophie der Mathematik» подразумевает под термином «вместе» также взаимный переход сторон друг в друга. Он утверждает, что такой переход происходит в каждой части ленты Мёбиуса и делает акцент не на "сторонах перехода», а «переходе сторон», обоснованно указывая на «освобождение» ленты Мёбиуса от «сторон». Философ обращает внимание на то, что «стороны уже не одна (внутренняя) и другая (внешняя) стороны вместе (обычное кольцо)»7, а края не один верхний и другой нижний вместе, но соединенные «вместе» ${ }^{8}$ внутренняя сторона как внешняя, внешняя сторона как внутренняя, верхний край как нижний, нижний край как верхний, то все они - стороны и края взаимоисключаются, осуществляя, таким образом, целостную фигуру Мёбиуса.

Учитывая вышеизложенное, мы можем сделать промежуточный вывод: лента Мёбиуса не может быть объектом с односторонней по-

\footnotetext{
${ }_{5}^{5}$ Гегель Г.В.Ф. Энциклопедия философских наук. М., $1974-$ 1977. T. 3. C. 12

${ }^{6}$ Маркс К., Энгельс Ф. Соч. Т. 46. Ч. 1. С. 29.

${ }^{7}$ Brükov Eugen. Philosophie der Zahlen / Eugen Brückov. Treuchtlingen; Berlin: Keller, 2001. S. 27.

${ }^{8}$ Ibid. S. 27.
} 


\section{Проблемы целостного мира}

верхностью и краем, так как в отличие от простого листа она не имеет частей. Если бы она имела одну сторону и один край, то в результате деления неизбежно приобретала бы вторую сторону с краем. В силу тех же свойств она не может быть более сложной фигурой - иметь две стороны. Лента Мёбиуса - это модель, о сторонах и краях которой нет смысла говорить, так как все пределы противоположностей прямоугольного листа в ленте Мёбиуса совпадая, становятся едиными. Становится совершенно ясным, что лента Мёбиуса - это уникальная пространственная фигура, в сфере которой, настолько просто, насколько это, возможно, осуществляется взаимный переход противоположных сторон друг в друга.

Описанный нами феномен пока не дает возможности утверждать о разрешении количественного парадокса ленты Мёбиуса, но указывает на то, что она может играть роль философского камня, где содержится величайшая идея единого, приоткрывшая свою тайну благодаря целостному подходу. «Каждая часть философии,- указывал Гегель,- есть философское целое, замкнутый круг, но каждая из этих частей содержит в себе философскую идею в ее особенной определенности ... Отдельный круг именно потому, что он есть в самом себе тотальность, прорывает границу своей определенности и служит основанием более обширной сферы ${ }^{1}$. Настало время провести границу между целым и целостностью, конечным и бесконечным, уничтожимым и вечным, делимым и неделимым, предельно целым и беспредельно единым.

В самом деле, если целое состоит из частей, то при делении, как мы уже упоминали выше, оно будет распадаться на части, не связанные между собой. То, что не имеет частей, не может их образовывать при делении. Продолжая эксперимент, попытаемся разрезать целый прямоугольный лист пополам по линии в пределах между A B и D C (Рис. № 10). Деление листа дает нам две самостоятельные и независимые друг от друга части $\mathrm{AB}$ и $\mathrm{CD}$, что характеризует его делимость.

Лента Мёбиуса при делении ее по центру образует вместо двух частей, как это можно было бы ожидать на примере обычного прямоугольного листа, одну длинную двухстороннюю

${ }^{1}$ Гегель Г.А.Ф. Энциклопедия философских наук. М., 19701972. T. 1. C. 100.

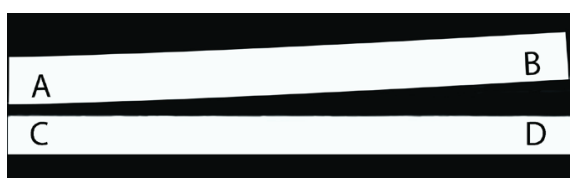

Рис. № 10 Обычный прямоугольныцй лист,

разделенный на две части: $A B$ и DC.

(вдвое больше чем сама лист Мёбиуса) ленту. Иными словами: лента Мёбиуса не распадается на части и сохраняет признаки целостного объекта.

Однако, умудренный опытом рациональной науки читатель обязательно укажет на противоречие, которое возникает в переходе от конечного - предельного, которым является обычный прямоугольный лист, к целостному беспредельному, на который претендует лента Мёбиуса, так как уже при первом делении она перестает быть таковой и формирует иную, отличную от себя форму: одну двухстороннюю (вдвое больше чем сам лента Мёбиуса) длинную ленту, называемую теперь «Афганской лентой». Если лента Мёбиуса теряет свою определенность или идентичность, то вместе с этим теряет и свои фундаментальные, атрибутивные свойства. Складывается ситуация, в которой объект, хотя не распадается на части, однако, дает основания говорить о новом количественном парадоксе.

Реальным критерием научности любой теории может выступать не только принцип наблюдаемости, но и принцип подтверждения изложенной теории воспроизводимым экспериментом. Из этого следует, что если лента Мёбиуса претендует на уникальность, то при делении должна не только сохранять свое единство, но и воспроизводить себя на своей собственной основе, указывая на свою неуничтожимость. В поисках эмпирического обоснования такой посылки нам представилась возможность найти такое решение, которое позволило решить эту поистине эвристическую задачу.

Известно, что при делении лента Мёбиуса может приобретать различные формы, такие, например, как «Узел трилистника», «Афганская лента», «Восьмерка»и другие неожиданные фигуры, которые принято называть «Парадромными кольцами». Несмотря на столь большое количество многообразий, их объединяет единая мебиусная основа, т.е. они качественное многообразие ленты Мёбиуса. 


\section{Философия и культура 12(72) • 2013}

Вполне очевидно, что двойные или тройные кольца - это лишь признаки более сильной напряженности, возникшей при нарушении целостной симметрии. Становится понятным, что напряженность, кратно увеличивающаяся при попытке деления ленты на части, «заставляет» кольца, «сжатые в пружину», вновь вернуться в свое исходное состояние - ленту Мёбиуса. Тщательный анализ мебиусных многообразий позволил сделать предположение: все объекты, имеющие качественную основу мёбиусной сферы, можно деформировать без склеиваний и разрывов в нее саму.

Так, с помощью выработанного алгоритма действий нам удалось деформировать Афганскую ленту в ленту Мёбиуса, сложив ее просто вдвое. То есть, двухсторонняя лента воспроизводит без самопересечений ленту Мёбиуса (рис. № 11). При этом нет возможности различить, какое из двух колец внутреннее, а какое наружное. Одновременно они - то и другое. Если бы лента Мёбиуса обладала границей, как утверждают многие ученые, то эта граница встала бы непреодолимой стеной на пути воссоздания ленты Мёбиуса, разделяя пространства.

Мы чувственно можем наблюдать, что лента Мёбиуса способна не только сохранять свое единство, т.е. не распадаться на части, но и умножать делением себя саму в себе самой из себя самой, оставаясь при этом неделимой. Это возвращает нас на деле к упомянутому вначале статьи высказыванию Мусея, что все рождается из Единого и разрешается в Едином. Указанный вывод сводит бесконечные споры о количественной стороне вопроса ленты Мебиуса к абсолютному минимуму, формируя, на этом пути, качественный взгляд на ее целостность.

Примечательно в этой связи отметить, что современный математик Габриэле Лолли сравнил философию с ангелом Вальтера Биньямина, который идет спиной вперед, глядя в прошлое. Более «прозаично» философия представлена им в виде портного, «который снимает мерки у клиента, не замечая, что тот продолжает расти» ${ }^{1}$. Несомненно, что наука далеко шагнула вперед, обеспечив прогресс во многих отраслях

\footnotetext{
${ }^{1}$ Габриэле Лолли. Философия математики: наследие двадцатого столетия / Пер. с итал. А.Л. Антакова, под ред. проф. Я.Д. Серегеева. Н. Новгород: Изд-во Нижненовгородского госуниверситета им. Лобачевского, 2012. С. 44.
}

знаний. Однако, современная теория множеств, сводит знание к языку аксиом, в соответствие с которыми самые современные системы могут эффективно функционировать, но не жить.

Рассуждая о проблеме целостности человека, П. С. Гуревич обращает внимание на то, что, несмотря на существование множественных суждений, частных замечаний и конкретных концепций многие авторы, обращаясь к этой проблеме, постулируют целостность человека, даже не подвергая тему философской рефлексии ${ }^{2}$.

Наблюдаемые нами в реальном пространстве ленты Мёбиуса целостные свойства, дают нам предпосылку утверждать, что единое является основанием для философской рефлексии - признаком живой науки, с помощью которой мышление, прежде чем дать чему либо определение, возвращается к своему первоначалу, пытаясь как бы вспомнить себя - начало бытия и ума и, сворачиваясь в одну точку, соотносит себя с единым. Разворачиваясь, мышление формирует большое многообразие философских систем, которые каждая по-своему освещают уникальность нашего Мира, аспекты его жизни. Оно создает универсалии культуры и науки и эксплицирует сферу духовной жизни человека. А.А. Корниенко высказала замечательную мысль о недостаточной оценке учеными мистики, которая подсказала науке многие идеи ${ }^{3}$. Так, Н. Кузанский - один из, пожалуй, самых мистических философов сформулировал еще в начале XIV века целостное понимание единого, как формы движения: «Как возникновение единства через единство, есть единичное повторение единства, так движение вперед одного и другого является повторением повторения этого единства, или, если это предпочтительнее, единством единства и равенством самого этого единства» 4 .

Из этого следует: единое - это не только название сущности, выступающей в качестве абсолютной причины вещи, но источник целостного мировоззрения, присущий человеку, который позволяет созерцать объективную природу на-

\footnotetext{
${ }^{2}$ Гуревич П.С. Проблема целостности человека. М., 2004. С. 4.

${ }^{3}$ Корниенко А.А., Квеско Р.Б., Макиенко М.А. и др. Философия. Учебное пособие. Томск: Изд-во ТПУ, 2007. C. 103.

${ }^{4}$ Кузанский Н. Избранные философские сочинения. Об ученом незнании. М., 1937. С. 19.
} 


\section{Проблемы целостного мира}

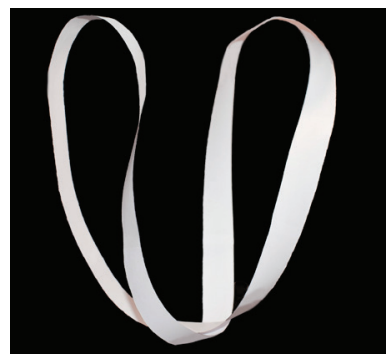

Рис.11. Протяженность мебиусной тенты, характеризующие ее иелостность.

блюдаемого, охватывая при этом и познаваемое и познающего. Учение о том, что «подобное познается подобным» философски уже отражено в учении Аристотеля «О душе»1. Иммануил Кант углубил это понимание благодаря «Критике чистого разума». Априорное мышление по его выражению есть «систематизированный инвентарь всего, чем мы располагаем» и который способен создать из самого себя «Метафизику природы»². Такой взгляд позволяет объяснить, почему мир познаваем.

Мы вправе утверждать, что истинные свойства целостности принадлежат человеку, как неделимой по природе сущности, поэтому нет ничего странного в том, почему он - человек может по своей воле конструировать мир, существующий по законам этой сущности. Н. Кузанский учил, что наш ум знает единое особенно и сразу⿰氵 ${ }^{3}$ Греческая философия по выражению Серра достигала в этом одной из своих величайших вершин. «Там, где человек пребывает в окружающем мире и сам выходит из этого мира, находится среди окружающей его материи и сам сотворен из нее, он перестает быть чужестранцем, и становится другом, членом семьи, равным среди равных» .

\footnotetext{
${ }^{1}$ Аристотель. О душе / Перевод П.С. Попова, испр. и доп. М.И. Иткиным с примеч. А.В. Сагадеева // Аристотель. Соч. в 4-х томах. М.: Мысль, 1976. Т. 1. С. 371-448.

${ }^{2}$ Кант И. Критика чистого разума / Пер. с нем. Н. Лосского, сверен и отредактирован Ц.Г. Арзаканяном и М.И. Иткиным; Примеч. Ц.Г. Арзакьяна. М.: Эксмо, 2006. 736 с. С. 16.

${ }^{3}$ Кузанский. Н. Избранные философские сочинения. Об ученом незнании. М., 1937. 362 с.

${ }^{4}$ Пригожин И. и Стенгерс И. Порядок из хаоса: Новый диалог человека с природой / Пер. с англ. Под общ. ред. и с послесл. В.И. Аршавина, Ю.Л. Климонтовича, Ю.В. Сачкова. Изд. 6-е. М.: Изд-во ЛлКИ, 2008. С. 253.
}

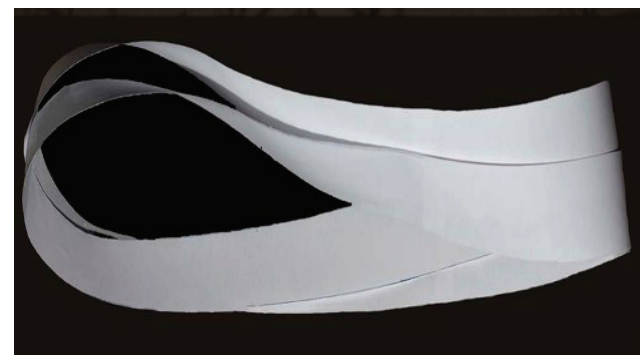

Рис. 12. Лента Мёбиуса, сложенная вдвое из одной длинной двухсторонней ленты и характеризуюшая единство.

Продолжая исследование, мы можем наблюдать (рис. № 11), как воспроизведение ленты Мёбиуса происходит на фоне протяженности одной сферы в другую. Обе сферы при вложении друг в друга ни больше, ни меньше друг друга, они абсолютно равны между собой и неразрывно связаны. При этом нет необходимости изрядно напрягать воображение, чтобы представить себе такие понятия как «протяженность», «непрерывность», «причинно-следственная связь», «взаимодействие», «движение», «устойчивость», «сохранение». Эти понятие впервые можно соотнести с реально наблюдаемым пространством мебиусной ленты. (рис. № 12). Если на первом рисунке (№ 11) сферы еще различаются и самопересекаются, то на втором - они вложены друг в друга и полностью совпадают. Все попытки установить связь между ними или определить их пресечение, остаются безрезультатными. Однако стоит только развернуть кольца, нарушив единство, пред глазами предстанут две сферы, имеющие общую протяженность.

Еще Р. Декарт, описывая вселенную, наделил ее целостными свойствами, которые проявляются в сохранении общего количества движения, что не может уменьшаться или увеличиваться, но которое перераспределяется в процессе взаимодействия при помощи протяженности материи. Не вызывает сомнений, что обычный прямоугольный лист становится лентой Мёбиуса за счет воссоздания целостной симметрии.

Спиноза, излагая свое видение субстанции, также обратил внимание на признаки протяженности. В его представлении она была единой, бесконечной, вечной и свободной способностью продолжения себя, своих собственных состояний или модусов. Он сформулировал положение о том, что субстанция существует 


\section{Философия и культура 12(72) • 2013}

\begin{tabular}{|c|c|c|}
\hline $\begin{array}{c}\text { Количество } \\
\text { делений }\end{array}$ & $\begin{array}{c}\text { Количество больших лент } \\
\text { после очередного разделения }\end{array}$ & $\begin{array}{c}\text { Количество малых лент, образуюших лист } \\
\text { Мебиуса после сложения большихент }\end{array}$ \\
\hline 0 & 0 & 0 \\
\hline 1 & 1 & 2 \\
\hline 2 & 2 & 4 \\
\hline 3 & 4 & 8 \\
\hline 4 & 8 & 16 \\
\hline 5 & 16 & 32 \\
\hline 6 & 32 & 64 \\
\hline 7 & 64 & 128 \\
\hline 8 & 128 & 256 \\
\hline 9 & 256 & 512 \\
\hline 10 & 512 & 1024 \\
\hline
\end{tabular}

Табл. № 1. Числа, отражающие количество делений - копий ленты Мёбиуса.

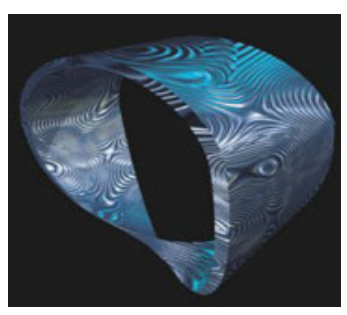

Puc. №13.

Логотип

мuccu Planck.

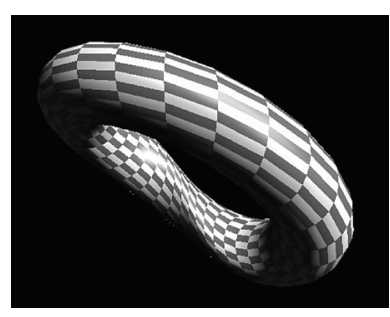

Puc. №14.

Мебиусная волна.

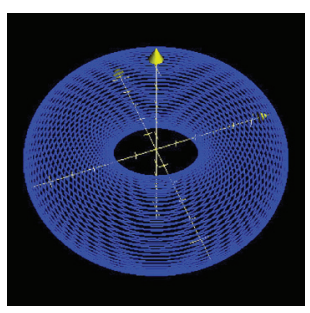

Puс. №15. Мебиусныц̆ тор с количеством волн 64.

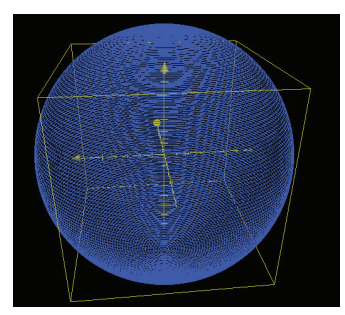

Рис. №16. Мебиусныьй шар с количеством волн 128. сама по себе и представляется сама через себя не нуждаясь во внешнем источнике.

Целостность, пожалуй, самая трудная в понимании, в силу ее трудной формализуемости, приобретает в ленте Мёбиуса свое адекватное очертание, выступая неким первоначальным инструментом мышления, отражающим здесь субстратный и динамический аспекты «мебиусного мира», важнейшим атрибутом которого выступает протяженность противоположных сторон друг в друга, обеспечивающая неделимость.

Поэтому каждый раз, когда мы пытаемся разделить ленту Мёбиуса пополам, она умножает лишь вдвое количество копий в своем пространстве, что демонстрирует: данный объект обладает признаком генезиса.

Генезис - это философская категория, которая выражает возникновение, происхождение, становление развивающегося явления ${ }^{1}$. Так,

\footnotetext{
${ }^{1}$ Большая советская энциклопедия. М., 1969-1978.
}

поднимаясь «по лестнице чисел», представленных в Таблице № 1, мы убеждаемся, что каждое новое число есть определенное количество единиц, маркирующих лишь количество копий мебиусной ленты при делении.

Этот эксперимент можно продолжать до тех пор, пока лента не исчезнет из пределов нашей видимости. Означает ли это, что она исчезает вообще? Теоретически лента Мёбиуса будет существует в другом, не доступном для нашего органа зрения, измерении, как сила, которая вечна и неуничтожима. Версия о том, что Вселенная имеет форму ленты Мебиуса ${ }^{2}$, т.е., что она замкнута сама на себя, была выдвинут немецким физиком Франком Штайнером (Frank Steiner) из университета Ульма. С тех пор на логотип мисси Planck помещена лента Мёбиуса (рис. № 13) Следуя версии физика, постараемся развить эту идею с помощью современных ком-

\footnotetext{
2 Электронный ресурс — www.abirura.com/modern_physics/ universum.htm.
} 


\section{Проблемы целостного мира}

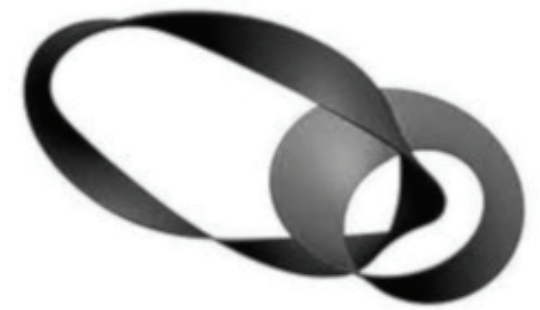

Рис. №17. Лента Мёбиуса и Абганская тента.

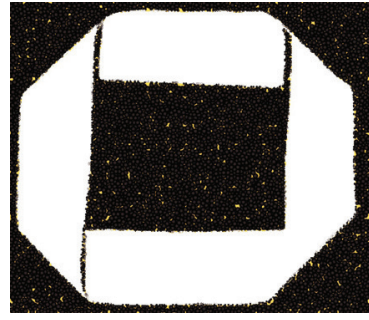

Puc. № 19.

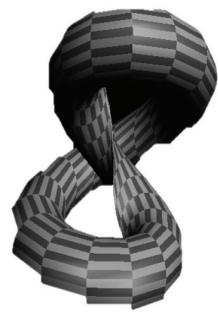

Puc. № 20. пьютерных технологий. Для этого воспроизведем ленту Мебиуса из тончайших мебиусных «волн», подобных рис. № 14. Тогда мебиусный Торус с количеством «волн» 64 (согласно таблице № 1) будет выглядеть, как это показано на рис. № 15 , а мебиусный шар с количеством «волн» 128 - как на рис. № 16.

Так как каждая «волна» имеет свое пространство, то вполне обоснованным является предположение, что каждое такое пространство может заполняться "волнами», создавая свое целостное пространство, а каждое такое постранство - свое, и так до бесконечности. При этом сами «волны» могут иметь самые разные формы преломления, такие, например, как: конус, куб, трилистник, восьмерка, «афганская лента», другие «пародромные кольца». В итоге это может дать многомерное пространство с единым верифицирумым законом неразрывности. Данное положение может позволить обобщить многие физические закономерности фундаментального взаимодействия, причинно-следственных связей, а также Закона сохранения.

В этой связи встает вполне обоснованный вопрос: является ли описанный нами опыт частным случаем или сфера мебиусного пространства действительно настолько уникальна, что может сохранять качественный индикатор целостности в ходе дальнейших преобразований?

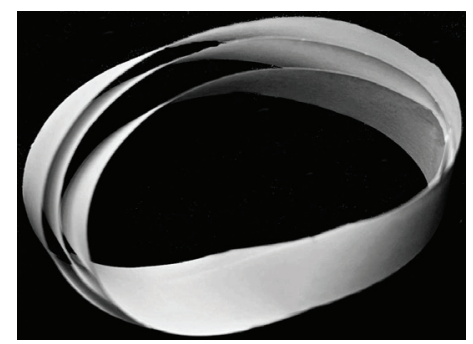

Рис. №18. Лист Мёбиуса, состоящий из 3 нераздельно связанных колеи.

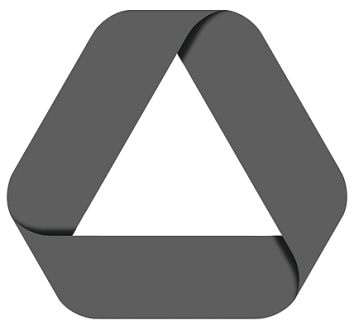

Puc. № 21.

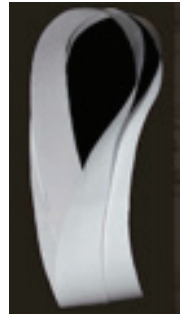

Puc. № 22.
Для ответа на этот вопрос, проведем очередной эксперимент. Разрежем ленту Мёбиуса, отступив от края на треть её ширины. В этом случае, как известно, получатся две связанные между собой ленты: одна короткая, собственно лента Мёбиуса, другая длинная с двумя полуоборотами - Афганская лента (рис. № 17).

С помощью уже выработанного алгоритма, как и в предыдущем эксперименте, мёбиусные ленты вкладываются в ленту Мёбиуса. При этом короткая лента и длинная вместе образуют три кольца (один в другом). Таким образом, при делении ленты Мёбиуса по принципу 1/3 ее пространство воспроизводит 3 мебиусные ленты (рис. № 18). Все ленты сохраняют самостоятельность и отсутствие самопересечений. Здесь становится понятной идея древних мыслителей, которые знали, что противоречивое многообразие, вызываемое тождеством, едино, что вероятно доказывает догадку старого Мёбиуса о возможности существования нулевых поверхностей. По этой причине не исключением будет являться и сделанный по принципу ленты Мёбиуса куб (рис. № 19).

В кубе также как и в мебиусном треугольнике каждый новый угол дополняет следующий, как внутренний, так и внешний. Следовательно, из прямоугольного листа получается квадрат с ограниченным количеством углов, где каждый предыдущий для последующего также 


\section{Философия и культура 12(72) • 2013}

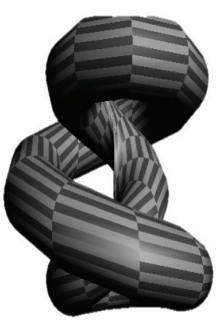

Puc. № 23 .

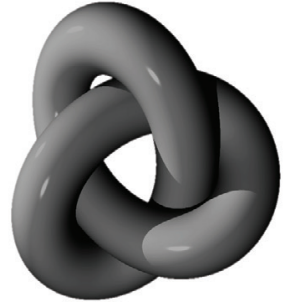

Puc. № 24.

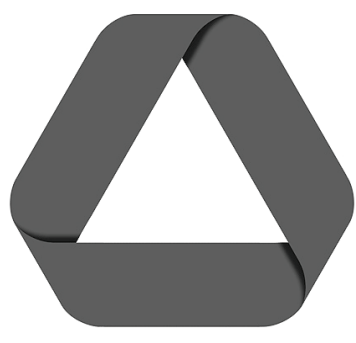

Puc. № 24.

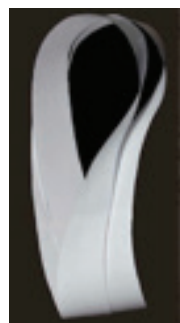

Puc. № 25. выступает как основа единства - целостности. В нем стороны и края переходят друг в друга и, создавая куб, снимают противоположности прямоугольного листа. После деления куба, который составляет пр. 360 ${ }^{\circ}$ (рис. № 19 и 20), он без склеиваний и разрывов воссоздает свою основу равностороннего треугольника (рис. № 21), т.е. ленту Мёбиуса с двумя вложенными друг в друга лентами (рис. № 22).

Известно, что если разрезать ленту с тремя полуоборотами (пр. $720^{\circ}$, рис. № 23), то получится лента, завитая в Узел трилистника (рис. № 24). Установленным способом узел Трилистника также деформируется без разрывов, склеиваний и растяжений в ленту Мёбиуса, или что, то же самое, приобретает форму равностороннего треугольника (рис. № 25), с двумя вложенными друг в друга мебиусными лентами (рис. № 26).

Таким образом, подтверждается одна из важнейших идей философии - идея тождества материи и пространства, что в качестве следствия обосновывает фундаментальное положение единства мира и его неуничтожимости.

Еще мыслители Античной философия предложили ряд глубоких и замечательных идей о взаимодействии как фундаментальном свойстве материи и источнике ее движения. Так, Аристотель показал не только взаимосвязь между категориями «действовать» и «претерпевать», но и обратил внимание на их взаимопереход. «Действие и претерпевание - учил он,- также допускают и противоположность себе»‥ Элеат закрепил идею Гераклита о взаимодействии, вызывающем взаимопревращаемость объектов. Эта мысль создала прочный фундамент для философии и естествознания будущих поколений. Особенно востребованными они становятся в период бурного становления науки. Так, Декарт расширил мысль

\footnotetext{
${ }^{1}$ Аристотель. Физика. Соч. в 4-х т. Т. 2. М., 1976. С. 79.
}

о взаимодействии его универсальностью, связав все материальные объекты механической передачей движения от одного предмета к другому. Гольбах, в отличие от Декарта, выделил в природе самодействующую систему, которая существует благодаря взаимодействию своих частей. Он понимал природу как великое целое, которое получается «от соединения различных веществ, их различных сочетаний и различных движений, наблюдаемых нами во вселенной»². Взаимодействие объектов Гольбах обосновывал их качественным многообразием. Идею взаимной связи объектов материального мира поддержал Ф. Энгельс, констатируя, что в ней «уже заключено то, что они воздействуют друг с другом, и это их взаимное воздействие друг на друга и есть именно движение. Уже здесь обнаруживается, что материя не мыслима без движения» ${ }^{3}$ $\Phi$. Энгельс придавал фундаментальное значение взаимодействию в природе материальных объектов, считая его источником и конечной причиной их существования. В отличие от качественной характеристики взаимодействия, Ньютон дал ему количественное обоснование, введя в научный оборот понятие «сила». Она характеризует у него механическое взаимодействие тел с точки зрения количества движения, которое передается одним предметом другому за единицу времени. Сила выступает понятием, которое объясняет причину изменения покоя и движения. Однако механистический взгляд на взаимодействие исключал взаимопревращаемость движения и покоя, поэтому материя представлялась неподвижной и аморфной. Возникало убеждение, что причина движения тела является чем-то внешним по отношению к нему, что она переносится с одного элемента на другой, создавая бесконечный причинный ряд.

\footnotetext{
${ }^{2}$ Гольбах И. Избр. произв. в 2-х томах. Т. 1. М., 1963. С. 72.

${ }^{3}$ Маркс К., Энгельс Ф. Соч. Т. 20. С. 544.
} 


\section{Проблемы целостного мира}

Совершенно ясно, что в научной среде возникли поиски первого активного члена причинного ряда (первоисточника). Если одни ученые видели в первопричине движения Бога, то другие пытались решить эту проблему на основе механистического взаимодействия. Можно предположить, что это мотивировало Спинозу сместить взгляд с одностороннего воздействия одного предмета на другой на предположение, обосновывающее взаимодействие предметов друг на друга. Он утверждал, что «природа является причиной самой себя» (Causa Sui) и она не нуждается во внешних силах. Гегель позже опишет это утверждение в своих трудах и укажет, что Спиноза смог выразить в общем виде идею взаимодействия ${ }^{1}$. Вслед за Гегелем идею взаимопревращаемости явлений в качестве существенного признака взаимодействия высказал $\Phi$. Энгельс. Он писал, что независимо от форм движения все они «переходят друг в друга, обусловливают взаимно друг друга, являются здесь причиной, там действием, причем общая сумма движения, при всех изменениях формы, остается одной и той же (спинозовское: субстанция есть causa sui - прекрасно выражает взаимодействие)»².

Таким образом, вся история развития философии и естествознания создает к середине XIX века прочную основу для понимания взаимопревращаемости объектов и явлений, что, в свою очередь, находит свое отражение в постулате: истина вещей - их взаимодействие. Категория "взаимодействие» в Философском словаре определяется как «процесс взаимного влияния тел друг на друга путем переноса материи и движения»3. Не случайно, что в начале $\mathrm{XX}$ века возникает гипотеза Пуанкаре. Ученый предположил, что все трехмерные объекты, которые обладают свойствами трехмерной сферы гомеоморфные ей, или, что любой трехмерный объект со свойствами трехмерной сферы можно деформироваться в нее саму. Анри Пуанкаре активно использовал в своих исследованиях ленту Мёбиуса и Трилистник, однако, прошел мимо их целостных свойств.

По нашему мнению, только лента Мёбиуса может обладать самой простой (то есть наименее

\footnotetext{
${ }^{1}$ Гегель Г.В.Ф. Соч. Т. 1. М.- Л., 1929. С. 255.

${ }^{2}$ Маркс К., Энгельс Ф. Соч. Т. 20. С. 544.

${ }^{3}$ Философский словарь / Под ред. И. Т. Фролова. 5-е изд. М.: Политиздат, 1987. 465 с.
}

сложной структурой) сферой - сферой, где снимаются все противоречия, в том числе противоречия между долготой, широтой и глубиной. Тогда логичней было бы назвать ее о-мерной или целостной сферой, где все многообразия не только сняты, но одновременно положены к становлению. Поэтому у нее нет и не может быть собратьев - только она сама. В этом мебиусная сфера уникальна. Обладая генезисом, она воспроизводит свои копии - качественные многообразия, которых, как мы полагаем, будет бесконечное множество.

Единство пространственной однородности мебиусной ленты, заключенное в сфере,- это очевидное место ее самоосуществления и прочная основа для последующих трансформаций. Взаимопревращение сторон друг в друга здесь немыслимо без взаимодействия и движения. И если категория «движение» «неразрывно связана со временем и пространством» ${ }^{4}$, охватывая долготу широту и высоту, то категория «взаимодействие» - с понятием «связь» 5 . Теперь мы видим, что связь - это не только понятие, но и имманентное свойство ленты Мёбиуса, обеспечивающее ей взаимный переход сторон друг в друга. Сущность ленты Мёбиуса, таким образом, проявляется в ее уникальной сфере, как производной от движения (цикличности взаимоперехода сторон) и, следовательно, как образное обобщение деформации сторон и краев прямоугольного листа, которые воздействуют на наши органы чувств.

Таким образом, становится очевидным, что, достигая в процессе становления целостной симметрии противоположности, сворачиваются в одну неделимую и неуничтожимую точку, оставляя лишь плоскостную иллюзию долготы широты и глубины. «Оконечность (extremitas) мира, таким образом,- писал Кузанец,- не состоит из точек: его оконечность - это округлость, заключающаяся в точке» ${ }^{6}$. Поэтому, когда поверх выкрашенной в разные цвета мебиусной ленты накладывается другая краска, возникает единый уже для бывших противоположных сторон цвет - цвет который совершенно ясно указывает на исчезновение частей. Тем

\footnotetext{
${ }^{4}$ Вернадский В.И. Философские мысли натуралиста. М.: Наука, 1988. С. 321.

${ }^{5}$ Философская энциклопедия. Т. 1. М., 1960. С. 250.

${ }^{6}$ Кузанский Н. Игра в шар. О видении Бога / Пер. с англ. В. В. Бибихина. М.: Академический проспект, 2012. С. 32.
} 


\section{Философия и культура 12(72) • 2013}

самым, противоположности не только положены к становлению в ленте Мёбиуса, но и сняты в ее уникальной сфере. Мы можем с большой уверенностью утверждать, что мебиусная сфера, как единое в своем роде пространство есть та сущность, в которой движение достигает своей цели. Движитель и движимое замыкаются в пространстве сферы, создавая в процессе взаимодействия вечное движение.

Не вызывает теперь сомнений, что целостная сфера является тем уникальным пространством, в котором заключены причинность и следствие, движение и покой, статическое и динамическое, в котором все противоречия свернуты в единое. В. И. Вернадский писал, что «Выражение - выразить все в «движении»отвечает сознанию выразить все в пространстве - времени» ${ }^{1}$. В этой связи, если мы хотим выразить все в движении, пространстве-времени - это может со всей очевидностью отвечать сознанию выразить все в уникальной сфере, где все качественное и количественное многообразие находится в возможности становления. Н. Кузанский утверждал: - «Точка не делима и не имеет ни количества, ни частей, ни переда, ни зада, ни каких бы то ни было других различий, не сополагаема ни с какой другой точкой»². Отсюда следует: если точка Евклида есть то, что не имеет частей, а концы любой лини суть точки, ${ }^{3}$ что, в свою очередь, означает ее неделимость, тогда две прямые параллельные линии, состоящие из точек, предопределенно будут стремиться к своему первоначалу, т.е. точке. И если мы нанесем маркером на противоположные края прямоугольного листа линии определённого цвета и сложим прямоугольный лист в ленту Мёбиуса, то убедимся, что линии совпали, образовав круг.

Итак, целостный способ объяснения свойств Мира, раскрывающий его устройство, основу строения, внутреннюю и внешнюю организацию, действительно существуют. Эти свойства достаточно ярко обнаруживаются в ленте Мёбиуса,

\footnotetext{
${ }^{1}$ Вернадский В.И. Философские мысли натуралиста. М.: Наука, 1988. С. 321.

${ }^{2}$ Кузанский Н. Игра в шар. О видении Бога / Пер. с англ. В. В. Бибихина. М.: Академический проспект, 2012. С. 32.

${ }^{3}$ Начала Евклида. Книги I-IV / Перевод с греч. и комм. Д. Д. Мордухай-Болтовского при редакционном участии И.Н. Веселовского. М.- Ленинград: Госиздат, 1950. С. 11.
}

подчиняясь строгому верифицируемому закону. Его сущность выражает протяженность нашего Мира, которая отвечает за его сохранение и устойчивое равновесие, обеспечивая, в тоже время, неуничтожимость. Опыт с лентой Мёбиуса доказывает, что Мир не может иметь «дырок», «границ»и «разрывов». Он безграничен, беспрерывен и вечен.

Поэтому при делении ленты Мёбиуса каждое ее новое качественное образование приобретает свойства предыдущей целостности, являясь одновременно и самостоятельной единицей и связью. В движении реализуется протяженность, где «предыдущее» для «последующего» всегда составляет единую и неделимую основу.

В процессе эксперимента нам удалось определить признаки формализующие целостность с выводами для целостных свойств ленты Мёбиуса, а также осуществить попытку, направленную на разделения понятий целое и целостность и несводимость одного к другому. Однако возник вопрос о концептуальном разграничении понятий «целостность» и «единство»и их отношении в суждениях. Кроме возникновения формально - логической проблематики, связанной с пониманием «единства» и его отношения с понятием «целостность» ${ }^{4}$ необходимо принять во внимание и методологические требования к определению этих понятий.

Как мы уже отмечали выше, единство во все времена рассматривалось как основа всех последующих построений. Единое - первовещество - составляли основную задачу мыслителей всех поколений. Н. Кузанский достаточно четко выразил это в своих работах: «единство» является синонимом от греческого слова $\omega \gamma$, которое по-латыни переводится ens (сущий), единство и сущность, обеспечивающие принцип бытия вещей ${ }^{5}$. В нашем случае - это принцип бытия ленты Мёбиуса, как целостной модели. Модель понятия целостности дает возможность нам не только коснуться единства, где сущность понимается лишь в возможности бытия мебиусной ленты, но и показать ее бытие, как принцип самоосуществления - взаимного превращения противоположностей друг в друга.

\footnotetext{
${ }^{4}$ Ильенков Э.В. Диалектика абстрактного и конкретного в «Капитале» Маркса. М., 1960. С. 45.

${ }^{5}$ Кузанский Н. Избранные философские сочинения. Об ученом незнании. М., 1937. С. 19.
} 


\section{Проблемы целостного мира}

Единство не количественно - оно качественно. Взаимный переход двух сторон осуществляется не разновременно (одна, а затем другая вместе), но одновременно (вместе одна и другая). Любая попытка подвергнуть исследованию стороны единого разновременно или выделить одну из его сторон, обособить ее, ведет к асимметрии единого - появлению частей и их уничтожению. «Простыми частями,- говорил еще Гегель, описывая члены и органы живого тела - становятся эти члены лишь под рукой анатома, но он тогда имеет дело уже не с живым телом, а с трупом ${ }^{1}$.

Сформулируем наше итоговое утверждение относительно единого, целостности и целого на примере ленты Мёбиуса. Если единое это сущность бытия ленты Мёбиуса, скрытая от наших органов чувств и лишь понимая, как нечто положенное к становлению и снятое, то целостность - это бытие сущности, как становящееся качественное многообразие противоположностей в единство, где движение - это вечная форма бытия сущности, заключающееся во взаимном проникновении материи через ее протяженность. Все то качественное многообразие лент, которое разворачивается из ленты Мёбиуса в результате ее деления, несет в себе признаки целостной симметрии и поэтому не утрачивает ее, но с еще большей энергией стремится вновь и вновь к своему единству, осуществляя движение.

Следовательно, целостность - это единство двух противоположных сторон в их движении и развитии, образующее уникальную интеграцию, устойчивую к деформации. Тогда целое,это объект, который хотя и обладает внутренней интеграцией, однако лишенный своих внешних связей в результате его выделения из целостного процесса становления, подвержен асимметрии и образованию частей, что неизбежно делает его неустойчивым к деформации.

Таким образом, у нас появился критерий, который позволяет выделить два класса явлений: целостные и нецелостные, метафизические и физические, указывая на беспредельность первых и предельность вторых. Эти критерии не могут мыслиться отдельно друг от друга, так как только вместе они способны решать важные мировоззренческие вопросы, взаимопроникая и дополняя друг друга до их единства - целостности. Метафизика, обладающая доопытным знанием о сущем и безусловном бытии, дает человеку вектор для чувственного познания окружающего Мира и как целостная наука участвует в обобщениях нового опыта, давая прирост новых знаний.

Данный критерий дает возможность, наконец, снять вопрос и о целостности человека и человеческой психики как феномена и говорить о его духовно-нравственной предопределенности, как единственного источника взаимодействия между людьми. Отрицание данного положения неизбежно будет вести к проблемам психики, деструктивности, аномии, к столкновениям в обществе и как следствие, к коллизиям истории.

Мы полагаем, что целостность содержит уникальный потенциал для разгадки многих количественных парадоксов в науке и философии. Несмотря на то, что целостность позволяет говорить об истине противоречивым языком и в парадоксальной форме - она наикротчайший путь к ней. В этой связи мы можем утверждать, что истина - это величайший парадокс на пути преодоления сомнений.

\section{Список литературы:}

1. Аристотель. Сочинения: в 4 т. М., 1975-1983.

2. Блауберг И. В. Проблема целостности и системный подход. М., 1997.

3. Вернардский В. И. Философские мысли натуралиста. М., 1988.

4. Гегель Г. В. Ф. Энциклопедия философских наук. В 3-х т. М., 1974-1977.

5. Гольбах И. Избранные произведения в 2-х т. М., 1963.

6. Грюнбаум Адольф. Философские проблемы пространства и времени / Пер. с англ. Изд. 2-е, соотнесённое. М., 2003.

7. Гуревич П. С. Проблема целостности человека. М., 2004.

${ }^{1}$ Гегель Г. А.Ф. Энциклопедия философских наук. М., 1970-1972. T. 1. C. 302. 


\section{Философия и культура 12(72) • 2013}

8. Начала Евклида. Книги I-IV / Перевод с греческого и комментарии Д. Д. Мордухай-Болтовского при редакционном участии И.Н. Веселовского. М., 1950.

9. Кант И. Критика чистого разума / Пер. с нем. Н. Лосского, сверен и отредактирован Ц. Г. Арзаканяном и М. И. Иткиным; Примеч. Ц. Г. Арзакьяна. М., 2006.

10. Кузанский Н. Игра в шар. О видении Бога Н. Кузанский / Пер. с англ. В. В. Бибихина. М., 2012.

11. Платон. Избранные диалоги / сост. и коммент. В. В. Шкоды. М., 2006.

12. Пуанкаре Анри. О науке. М., 1983.

13. Brükov Eugen. Philosophie der Zahlen / Eugen Brückov. Treuchlingen; Berlin: Keller, 2001.

14. Nikolaus von Kues. Philosopisch-theologische Werke. 4 Bänder. Felix Meinder Verlag, Hamburg, 2002.

15. References (transliteration):

16. Aristotel». Sochineniya: v 4-h t. M., 1975-1983

17. Blauberg I. V. Problema tselostnosti i sistemnyi podkhod. M., 1997.

18. Vernardskii V. I. Filosofskie mysli naturalista. M., 1988.

19. Gegel» G. V. F. Entsiklopediya filosofskikh nauk. V 3-h t. M., 1974-1977.

20. Gol'bakh I. Izbrannye proizvedeniya v 2-h t. M., 1963.

21. Gryunbaum Adol'f. Filosofskie problemy prostranstva i vremeni / Per. c angl. Izd. 2-e, sootnesennoe. M., 2003.

22. Gurevich P. S. Problema tselostnosti cheloveka. M., 2004.

23. Nachala Evklida. Knigi I-IV / Perevod s grecheskogo i kommentarii D. D. Mordukhai-Boltovskogo pri redaktsionnom uchastii I. N. Veselovskogo. M., 1950.

24. Kant I. Kritika chistogo razuma / Per. s nem. N. Losskogo, sveren i otredaktirovan Ts.G. Arzakanyanom i M. I. Itkinym; Primech. Ts.G. Arzak'yana. M., 2006.

25. Kuzanskii N. Igra v shar. O videnii Boga N. Kuzanskii / Per. s angl. V. V. Bibikhina. M., 2012.

26. Platon Izbrannye dialogi / sost. i komment. V. V. Shkody. M., 2006.

27. Puankare Anri. O nauke. M., 1983. 